UDK 681.818(497.4)

Darja Koter

Pokrajinski muzej Ptuj

Regional Museum Ptuj

\title{
Izdelovalci pihal na Slovenskem in njihova dediščina
}

\section{Uvod}

Domača glasbenozgodovinska stroka se kljub vse širši razvejanosti razvoju glasbilarstva v naših krajih še ne posveča prav dolgo, zelo redke pa so tudi omembe v tuji literaturi. Izsledki dosedanjih raziskav tako nakazujejo številne iztočnice za nadaljnje poglabljanje $\mathrm{v}$ tematiko o zgodovini izdelovanja instrumentov na Slovenskem. Poti do odgovorov na vprašanja je veliko, med najbolj povednimi pa so gotovo ohranjeni instrumenti, na katerih najdemo signature izdelovalcev. V našem okolju se je ohranilo bolj malo historičnih glasbil, pa čeprav je za stoletja nazaj dokazan intenziven poustvarjalni glasbeni utrip. Posamezniki, glasbene šole, cerkvene in muzejske ustanove ter drugi so se le redko zavedali pomena starih oziroma odsluženih glasbil, zato so bila mnoga med njimi prepuščena pozabi in propadu. Toda vsem tegobam navkljub se je v slovenskih muzejih ter pri zasebnikih ohranila pomembna bera historičnih instrumentov, izdelanih pri nas in drugod, ki nas najbolj verno vodi po sledeh nekdanje glasbene poustvarjalnosti, hkrati pa nakazuje podobo glasbenih obrti.

Od prvih dognanj o obrtnikih, ki so se v preteklosti posvečali izdelovanju glasbil, so minila le dobra tri desetletja, med izjeme pa štejemo nekaj zgodnejših omemb o orglarjih. Ugotovitev temelji na upoštevanju tistih izdelovalcev in njihovih evidentiranih izdelkov po muzejih doma in drugod, pri katerih lahko na predmetu razberemo signaturo oziroma se kako drugače približamo delavnici ali posameznemu mojstru. Nekatera imena pa so dokazana zgolj preko neposrednih in posrednih pisnih virov. Prve omembe glasbilarjev, delujočih v naših krajih, so znane iz tuje literature. Cyril Woodcock je v svojem leksikonu o goslarjih ${ }^{1}$ objavil ducat izdelovalcev violin, ki jih danes prištevamo med slovenske mojstre. ${ }^{2}$ Njegovo delo je nekaj let

1 Cyril Woodcock, Dictionary of contemporary Violin and Bowmakers, Brighton 1965. 
kasneje dopolnil Renne Vannes. ${ }^{3}$ Toda tudi Vannesev leksikon, ki je za zgodovino izdelovanja godal sicer eden najpomembnejših sploh, je v delih, kjer navaja naše mojstre, potreben revidiranja. $\mathrm{V}$ zadnjem času je obravnavani temi posvečenih več študij, a rezultati raziskav še zdaleč niso popolni. ${ }^{4}$ Podobno velja za proučevanje drugih glasbilarskih obrti. Prvo objavo je o splošnem izdelovanju glasbil prinesel jugoslovanski leksikon Muzička enciklopedija leta $1974 .^{5} \mathrm{~V}$ geslu o razvoju izdelovanja glasbil, razdeljenem na poglavja po posameznih republikah, najdemo nepodpisan prispevek o glasbilarstvu na Slovenskem. V kratkem je navedenih nekaj imen in drugih podatkov o zgodovini izdelovanja orgel, klavirjev, godal, brenkal in harmonik. Druge instrumentalne družine, kot so pihala, trobila in tolkala, niso obravnavane. Ker to geslo ne prinaša nikakršnih podatkov o uporabljenih virih in literaturi, ga je potrebno ustrezno preveriti in dopolniti. Dvajset let kasneje je izšel Leksikon jugoslavenske muzike (Zagreb 1984), v katerem bi pričakovali obsežnejšo obravnavo tega dela glasbene zgodovine, vendar ima tamkajšnje sicer enako poimenovano geslo le malo ustreznih dopolnitev, pri čemer ponovno pogrešamo proučevanje pihal, trobil in tolkal. ${ }^{6}$ Pregled literature tako naravnost vabi k nadaljnjim raziskavam, še posebno, ker imamo po slovenskih muzejih ter pri zasebnikih nekaj zelo zanimivih historičnih instrumentov domačih mojstrov, $v$ arhivih pa dokaj bogate, za omenjeno področje domala še neizkoriščene vire. Zgodovinsko ozadje glasbilarstva je doslej najbolj pritegnilo proučevalce orglarstva, ${ }^{7}$ zato so orgle posebno v zadnjih desetletjih deležne bolj vsestranske pozornosti v smislu raziskovanja in ohranjanja kot druge glasbilarske obrti.

Prispevek je namenjen zgodovinskemu razvoju izdelovanja pihal, posameznim strugarjem in njihovim izdelkom, s čimer želimo vsaj v obrisih dopolniti sliko o pojavu in razvoju glasbilarstva, o ohranjeni dediščini ter o stopnji razvitosti tako imenovanih glasbenih obrti v domačem okolju. Nadalje nas zanima, kako daleč nazaj segajo dokazi o izdelovanju pihal pri nas, kolikšne so bile potrebe po strugarjih, kdo so bili posamezni mojstri, prišleki ali domačini in ne nazadnje je pomembno spoznati pomen te dediščine ter njeno vpetost $\mathrm{v}$ evropsko glasbeno kulturo. Številna in raznolika vprašanja se ne navezujejo na tradicijo izdelovanja glasbil, namenjenih ljudskemu izročilu, kajti obravnava tega gradiva zahteva spet drugačno metodologijo dela, poleg tega pa so ljudska glasbila in njihovo nastajanje pogosteje deležna strokovne pozornosti. ${ }^{8}$ Glasbil sicer ne moremo dosledno deliti na ljudska

2 Woodcock je nekatere goslarje, ki jih danes deklariramo kot slovenske ali vsaj na Slovenskem delujoče, uvrstil med srbske. Takšna oznaka nejverjetneje ne določa nacionalnosti ampak je z njo označena pripadnost nekdanji jugoslovanski državi.

3 Renne Vannes, Dictionaire Universal des Luthiers, Les amis de la Musique, Bruxelles 1979.

4 Prim. Andreja Pungartnik, Slovenski izdelovalci godal v našem stoletju (diplomska naloga), Ljubljana 1990. Tipkopis hrani knjižnica Pedagoške fakultete v Ljubljani; Darja Koter, Pojav in razvoj delavnic glasbil ob glasbenem šolstvu na Slovenskem (doktorska disertacija), Ljubljana 1998. Tipkopis hrani knjižnica Akademije za glasbo v Ljubljani.

5 Prim. Muzička enciklopedija II (ur.Krešimir Kovačević), Zagreb 1974, str. 6, geslo: Građenje umjetničkih muzičkih instrumenata.

6 Prim. Leksikon jugoslavenske muzike I, II (ur,Krešimir Kovačević), Zagreb 1984, str. 286, geslo: Gradenje umjetničkih muzičkih instrumentata.

7 O izdelovanju orgel na Slovenskem so poleg nekaterih starejših avtorjev s konca prejšnjega in začetka tega stoletja največ pisali Ladislav Šaban, Edo Škulj in Milko Bizjak. 
in neljudska, vendar so prva zanimivejša za glasbenonarodopisne raziskave. V danem prispevku namenjamo največ pozornosti izdelovanju glasbil v obrtnih delavnicah urbanega okolja, ki so služile različnim potrebam poustvarjalcev umetne glasbe.

\section{Dejavniki, ki so vplivali na razvoj glasbilarstva}

Razvoj izdelovanja instrumentov je med drugim tako kot drugod po svetu tudi pri nas tesno povezan s splošnim kulturnim utripom v deželi, še posebno pa $s$ poustvarjalnimi navadami okolja. Zgodovinska dejstva nas prepričajo, da so bila umetniška gibanja $\mathrm{v}$ naših krajih posebno od 14. stoletja naprej precej živahna. Kažejo tudi veliko skupnega $\mathrm{z}$ glasbenim življenjem sosednjih dežel severno in zahodno od nas. Instrumentalna glasba je že v prvi polovici drugega tisočletja zagotovo imela svoje mesto med plemiškimi in meščanskimi krogi, kjer tudi pričakujemo največ poustvarjalnih spodbud. Iz dežele v deželo so jih med drugimi prenašali popotniki višjih slojev, ki so se tako ali drugače glasbeno izražali. Gospodarska in kulturna gibanja pa so že stoletja nazaj narekovala preseljevanja prebivalstva, tudi izobraženstva. K nam so tako stoletja prihajali svetni imenitneži ter člani različnih samostanskih redov, oboji nemalokrat $z$ odlično glasbeno izobrazbo. Ne nazadnje ne moremo obiti tistih vsestransko razgledanih domačinov, ki so se šolali v tujih mestih in se kasneje vračali domov, najverjetneje $v$ glasbi dobro podkovani. Ko se je glasbeno življenje v 16. stoletju še bolj razgibalo, se je precej povečalo število cerkvenih orgel ter razmahnilo domače muziciranje $\mathrm{v}$ svetnem in duhovnem okolju. Od preloma v naslednje stoletje pa do danes je dokazov o instrumentalnem igranju vse več, prav tako pa tudi o rabi glasbil, posameznih izdelovalcih ter nenazadnje o trgovanju $\mathrm{z}$ instrumenti. Časovni trak poustvarjalnih navad združuje vedenja o muzikih v plemiškem, samostanskem, cerkvenem ter v širšem mestnem okolju, o glasbenih društvih in akademijah, zasebnem in institucionalnem šolstvu, razvoju gledališča $z$ ansambelsko in orkestralno igro ter ne nazadnje o številnih drugih vzgibih instrumentalnega igranja pri nas. ${ }^{9}$ Dinamika glasbenega življenja, njegova raznolikost in kvaliteta sta nedvomno dovoljšen dokaz za prepričanje, da so poustvarjalne navade eden izmed temeljev za razvoj glasbilarskih obrti. Čeprav so dosedanje študije pokazale, da so glasbeni instrumenti v veliki meri prihajali $\mathrm{k}$ nam po trgovskih poteh, ne moremo obiti sledi, ki nas seznanjajo $z$ izdelovanjem glasbil v našem neposrednem okolju. Tako kot skušamo poiskati stičišča med glasbeno poustvarjalnostjo in razvojem glasbilarskih obrti, jih zagotovo najdemo tudi v povezavi $\mathrm{z}$ nastajanjem in naraščanjem zasebnega ter institucionalnega glasbenega šolstva. ${ }^{10}$ Zagotovo ni naključje, da se podatki o glasbilarjih zgoščujejo skupaj z intenzivnejšim raz-

8 Zgodovini izdelovanja ljudskih glasbil pri nas se posvečajo različni avtorji, najbolj izčrpne ugotovitve pa najdemo v glasbenonarodopisnih delih Zmage Kumer, Julijana Strajnarja, Mire Omerzel-Terlep, Marka Terseglava, Igorja Cvetka in drugih.

9 Zgodovino poustvarjalnih navad so proučevali številni avtorji, med katerimi naj omenimo le nekaj najpomembnejših za starejša obdobja, kot so Dragotin Cvetko, Andrej Rijavec, Janez Höfler, Primož Kuret, Danilo Pokorn, Manica Špendal, Jurij Snoj, Jože Mlinarič in drugi.

10 O zgodovini glasbenega šolstva pri nas je najizčrpneje pisal Cvetko Budkovič v knjigi Razvoj Glasbenega šolstva na Slovenskem I, od začetka 19. stoletja do nastanka konservatorija (Ljubljana 1992). 
vojem poučevanja instrumentov, in sicer od druge polovice 18. stoletja dalje. Splošna gospodarska in obrtna gibanja našega širšega okolja so prav tako pomembna za obrtne panoge pričujoče obravnave. Tako ugotavljamo, da so od druge polovice prejšnjega stoletja nekatere sicer uspešne delavnice zamrle kljub vse večjim potrebam po glasbilih, čemur so botrovale gospodarske razmere v deželi. Tako kot na drugih področjih, so tudi v glasbenih obrteh nastajali večji, ekonomsko uspešnejši centri, ki so manjše obrtnike nemalokrat potisnili na rob preživetja. Pri nas so le redki posamezniki kljubovali konkurenci razvitejših krajev.

\section{Zgodovina strugarske obrti in izdelovanja pihal na Slovenskem}

O strugarjih, ki jih v skladu $\mathrm{z}$ evropsko tradicijo povezujemo $\mathrm{z}$ izdelovanjem pihal, je najzgovornejše gradivo $\mathrm{v}$ Ljubljani, ${ }^{11}$ deloma pa tudi $\mathrm{v}$ nekaterih drugih slovenskih mestih, kot sta Ptuj ${ }^{12}$ in Maribor. ${ }^{13}$ Pri pregledovanju starejših arhivskih virov o obrteh, cehovstvu in bratovščinah ne najdemo samostojne skupnosti izdelovalcev glasbil. Prvo tovrstno združenje pri nas je znano šele leta 1883, ko je v Mariboru po dokončni odpravi cehovstva nastala zadruga mizarjev, strugarjev in orglarjev. ${ }^{14}$ Pred tem pa so se najverjetneje glasbilarji tako kot marsikje drugod pridruževali združenjem drugih strok. O obrtnikih domačih srednjeveških mest je le malo znanega. Med prvimi, omenjenimi v 14. stoletju, ni strugarjev, pojavijo se šele $\mathrm{v}$ naslednjem stoletju, ko so se obrti zaradi naraščanja prebivalstva in vse večjih potreb plemstva in drugih bogatejših slojev razraščale. ${ }^{15}$ Prvi ljubljanski znani strugar, ki ga po vicedomskem urbarju iz leta 1496 omenja Božo Otorepec, je bil neki Anže na Starem trgu ob koncu 15. stoletja ${ }^{16}$ Kasneje ljubljanskim strugarjem sledimo preko sodnih protokolov in knjig prejemkov, s čimer se je izčrpno ukvarjal Ivan Slokar, ${ }^{17}$ omenjajo pa jih tudi davčne knjige. ${ }^{18} \mathrm{O}$ strugarjih, ljubljanskih meščanih je največ znanega za obdobje po letu 1600, ko se je rokodelstvo vse bolj specializiralo. Slokar je iz knjige mestnih prejemkov, ki zajema čas od 1610-1731, izluščil nekaj strugarjev. V prvem obdobju od 1610-40 je zabeležen eden, v naslednjem (16411670) sta bila dva, med letoma 1671 in 1731 pa trije. ${ }^{19}$ Žal jih ne poznamo po imenih, prav tako pa ne vemo, ali so se ob običajnih strugarskih izdelkih posvečali tudi glas-

11 Obsežno rokopisno gradivo o obrteh je zbrano in objavljeno v zbornikih razprav Zgodovinskega arhiva Ljubljane (prej Mestni arhiv Ljubljane), Razprave MAL, zv. 1, 2, 3, Ljubljana 1971, 1972, 1977. Publikacije obravnavajo rokopisno gradivo, povezano $\mathrm{z}$ različnimi obrtmi, tudi s strugarstvom.

12 Prim. Marija Hernja Masten, Vpisna knjiga meščanov mesta Ptuja 1684-1917, Zgodovinski arhiv Ptuj (ZAP), Rokopisna zbirka sign. R 30, Viri 1, Ptuj 1995.

13 Prim. Antoša Leskovec, Razvoj gospodarstva v Mariboru 1752-1941, v: Maribor skozi stoletja, Razprave I, Maribor 1991, str. 331.

14 Ibidem.

15 Glej, Razprave MAL, Ibidem.

16 Prim. Božo Otorepec, Rokodelstvo in obrt v srednjeveški Ljubljani, V: Ljubljanska obrt od začetka srednjega veka do začetka 18. stoletja, Razprave MAL, zv.3, Ljubljana 1972, str. 16.

17 Prim. Ivan Slokar, Rokodelstvo in industrija v Ljubljani od konca srednjega veka do leta 1732, v: Ljubljanska obrt ..., str. 55-113.

18 Prim. Vlado Valenčič, Pregled ljubljanskega obrtništva v 17. stoletju, v: Ljubljanska obrt..., ibidem, str. 143-151.

19 Prim. I. Slokar, ibidem, str. 60. 
bilom. Ob pomanjkanju trdnejših dokazov ter ob upoštevanju zgodovinskega glasbenega ozadja predvidevamo, da potrebe po lesenih pihalih $\mathrm{v} 17$. in $\mathrm{v}$ prvih desetletjih 18. stoletja še niso narasle do te mere, da bi nudile dovolj zaslužka za preživetje domačinom ali da bi spodbujale k naseljevanju tujce. Pri iskanju morebitnih strugarjev izdelovalcev glasbil so nadvse pomembne davčne knjige, saj vsebujejo podatke o vrstah obrti in številu rokodelcev za posamezna obdobja. Za 17. stoletje in tja do konca prve tretjine 18. je v ljubljanskih knjigah vpisanih kar nekaj strugarjev. V Valenčičevi preglednici obrtnikov najdemo po enega strugarja za leto 1630 in 1640, po dva v naslednjih dvajsetih letih, nato spet enega in ob koncu 17. stoletja, leta 1690 tri. $^{20} \mathrm{~V}$ publikacijah ljubljanskega mestnega arhiva so omenjeni tudi za naslednja obdobja. V 18. stoletju je prišlo do delitve na osebne in realne obrti. Pravice prvih, namenjene le eni osebi, so bile prenosljive, druge, vezane na določeno hišo, pa je bilo mogoče odsvojiti. Za preskrbo vdov mojstrov in za nasledstvo otrok so razvili sistem dedovanja, ki je pomenil nastanek civilnopravnih prenosljivih realnih obrtnih pravic. ${ }^{21}$ Glasbilarske obrti so se prenašale po pravilih realnih obrti, zato je bilo povsem običajno, da so vdove med mojstri ustreznih znanj kaj hitro našle drugega moža. Od srede 18. stoletja so družbena in gospodarska gibanja zahtevala $\mathrm{k}$ obrtni zakonodaji nove dopolnitve, toda do večjih sprememb je prišlo šele po marčni revoluciji, in sicer $z$ uvedbo obrtne svobode, ki je razlikovala proste in koncesionarne obrti, kar je uzakonil obrtni zakon leta 1859. Za odprtje proste obrti je bila dovolj prijava brez dokazil o znanju, druge pa so bile odvisne od javnih interesov in zato tolikanj težje dosegljive. Ta zakon je doživljal številne kritike in zahteval dopolnila, ki so se v ne preveč posrečeni obliki udejanila leta $1883 \mathrm{z}$ uvedbo tretjih, tako imenovanih rokodelskih obrti, za katera pa je bilo potrebno ob prijavi priložiti tudi dokazila o kvalifikaciji. Slednje obrti so poslej prevladovale pri nas. Cehovska združenja so z letom 1883 dokončno ukinili, svoje pravice in dolžnosti pa so obrtniki poslej uveljavljali preko takrat ustanovljenih obrtnih zadrug. Naslednji obrtni zakon je bil uveden šele v prvi Jugoslaviji, leta 1931, ki pa se od starega avstrijskega ni bistveno oddaljil. ${ }^{22}$

Za proučevanje strugarstva in $\mathrm{z}$ njim povezanega izdelovanja pihal je najpomembnejše obdobje od druge polovice 18. stoletja. Tako vemo, da je Ljubljana imela okrog leta 1744 štiri strugarje, nato do leta 1762 le dva, v letu 1773 nikogar, med letoma 1786 in 1799 spet dva in v začetku 19. stoletja so registrirani trije. ${ }^{23} \mathrm{~V}$ letu 1809, ko je francoska oblast ukinila cehe in realne obrti ter uvedla obrtno svobodo, so bili v Ljubljani trije strugarski mojstri in dva pomočnika. Po restavraciji avstrijske oblasti, leta 1814 , ko je ponovno začela veljati avstrijska zakonodaja od prej, pa so zabeleženi štirje mojstri in dva pomočnika. Med mojstri je imel eden posebno pravico s patentom in vse kaže, da si je takšne privilegije zaslužil Simon Unglerth, o katerem bomo govorili v nadaljevanju. V letih do 1860 je število strugar-

20 Prim. V. Valenčič, ibidem, str. 148.

21 Prim. Sergij Vilfan, Pravna zgodovina Slovencev, Ljubljana 1996, str. 390-391.

22 Ibidem, str. 479-480.

23 Prim. I. Slokar, Zgodovina rokodelstva $v$ Ljubljani od leta 1732 do leta 1860, v: Ljubljanska obrt od začetka 18. stoletja do srede 19. stoletja, Razprave MAL, zv. 4, Ljubljana 1977, str. 25. 
jev nihalo med štiri in pet, ${ }^{24}$ podobne številke pa razberemo tudi iz davčnih knjig in tako imenovanih obrtnih registrov. ${ }^{25}$ Ker viri o cehovstvu v Ljubljani ne omenjajo samostojnega ceha strugarjev, je po vzorih sosednjih večjih mest povsem mogoče, da so bili ti obrtniki priključeni mizarskemu cehu.

Arhivsko gradivo večkrat navaja, da je veliko dobrih mizarskih izdelkov prihajalo z Dunaja, kar je posebno značilno za čas od začetka 19. stoletja naprej, zato so se domači mizarji organizirali v "rokodelsko prodajno zadrugo", ustanovljeno leta 1826. ${ }^{26}$ Med trgovskim blagom so s cesarskega mesta zagotovo prihajala tudi glasbila, o čemer pričajo oglasi v časopisu Laybacher Zeitung ter ohranjeni eksponati v slovenskih muzejih. Čeprav je iz oglasov razvidno, da je najbolj cvetela trgovina $s$ klavirji, so zagotovo trgovali tudi s pihali. Slika instrumentalne dediščine namreč kaže, da je bila večina pri nas ohranjenih pihal izdelana v dunajskih delavnicah, nekaj je graških izdelkov, manj tovrstnih eksponatov pa je prišlo k nam od drugod.

$\mathrm{V}$ avstrijski monarhiji so po zgledu drugih dežel pripravljali večje in manjše obrtno-industrijske razstave. $\mathrm{V}$ ta namen je bilo v tridesetih letih prejšnjega stoletja $\mathrm{v}$ Gradcu kot središču notranjeavstrijskih dežel, ki so obsegale tudi ozemlje današnje Slovenije, ustanovljeno notranje-avstrijsko obrtno združenje, ki naj bi med drugim prirejalo razstave, na katerih so se predstavljali uspešnejši obrtniki manjših mest monarhije. Takšna prireditev je bila leta 1838 v Celovcu, tri leta za tem v Gradcu in leta $1844 \mathrm{v}$ Ljubljani. ${ }^{27}$ Poročila pravijo, da je ljubljanska razstava s skupno 284. razstavljalci prekosila obe prejšnji, obiskal pa jo je tudi sam avstrijski cesar Ferdinand I. Na obrtnih razstavah so iskali svojo priložnost za potrditev kakovosti tudi izdelovalci glasbil. Na ljubljanski razstavi sta sodelovala dva, Andrej Bitenc (Andreas Wittenz), izdelovalec klavirjev in Simon Unglerth, strugar in izdelovalec pihal, ${ }^{28}$ oba iz Ljubljane (op. D. Koter). Prvi je za svoje izdelke prejel srebrno, drugi pa bronasto medaljo. ${ }^{29}$ Žal pa o njunih razstavnih eksponatih ne vemo ničesar. Morda je bil prav Unglerth tisti izbranec, ki si je s kvaliteto izdelkov prislužil posebne obrtne privilegije, ${ }^{30}$ tako imenovani patent, kakor je bilo omenjeno. Unglertha najdemo tudi med lastniki ljubljanskih hiš v popisu iz leta 1830, kjer piše, da je družina Simona Unglertha stanovala v Kapucinskem predmestju št. $41 .{ }^{31}$ Poleg Simona (r. 1778), lastnika hiše št. 40 in 41, po poklicu strugarja ("drechlermeister") sta vpisana njegova žena Lucija (r. 1784) in sin Ferdinand (r. septembra 1811). ${ }^{32}$ Zanimivo, da je kot lastnik

24 Ibidem, str. 59.

25 Prim. V. Valenčič, Pregled ljubljanske obrti od začetka 18. stoletja do obrtnega reda iz leta 1859 ter njen gospodarski in družbeni razvoj, ibidem, razpr. 4, str. 140 in 142.

26 Ibidem, str. 72.

27 O tem J. Slokar, Zgodovina rokodelstva v Ljubljani od leta 1732 do leta 1860, ibidem, str. 78-82.

28 Ibidem, str. 84.

29 Ibidem, str. 84.

30 Sergij Vilfan razlaga privilegij kot pravico, ki je bila v fevdalnem pravnem redu in še naprej dana posamezni osebi, kraju ali skupinam oseb. (Glej S. Vilfan, ibidem, str. 90). V gospodarskem pravu je bila posebno od prve polovice 18. stoletja naprej razširjena pravica do izključne proizvodnje določene vrste blaga ali do proizvodnje $z$ določenim postopkom, imenovana privilegium privatum, ki se ga je prijelo poimenovanje "patent . (O tem glej v S. Vilfan, ibidem, str. 306).

31 Zgodovino poimenovanje predelov v Kapucinskem predmestju, danes je to sklop ulic okrog Kongresnega trga, je proučeval Vlado Valenčič, svoje izsledke pa objavil v knjigi Zgodovina ljubljanskih uličnih imen (Ljubljana 1989). 
Slika 1. Čakan, Simon Unglerth, Ljubljana, zg. 19. st., instrument hrani Musikhistorisk Museum og Claudius' Samling, København, foto: Ole Woldbye.

hiše v tem delu mesta, vendar na številki 14 vpisan isti priimek, in sicer družina strugarja Franza Unglertha (r. 1811 tako kot Ferdinand, Simonov sin). Zaenkrat ni dokazov, da bi bili družini povezani oziroma da bi bila omenjena zaradi napake pri vpisu celo isti osebi. Nemška muzikologinja Marianne Betz, ki je Unglerthovo življenje in delo prva raziskovala, meni, da je Ferdinand verjetno zelo zgodaj umrl, ${ }^{33}$ o čemer pa ni dokazov. Franz Unglerth je imel ženo Anno (r. 1811), štiri sinove (Rajmund, r. 1837, Albin, r. 1839, Maximilijan, r. 1841 in Ferdinand, r. 1845) in dve hčeri (Rozalija, r. 1844 in Marija, r. 1848). ${ }^{34} \mathrm{~V}$ rubriki, kjer je naveden poklic, v primeru

32 Zgodovinski arhiv Ljubljane (ZAL), Conscriptions Aufnams Bögen der Kapuziner Vorstadt vom Jahr 1830 , Bogen 17, šk. 34.

33 Prim. Marianne Betz, Der Czakan und seine Musik: Wiener Musikleben im Frühen 19. Jahrhundert, dargestellt am Beispiel einer Spazierstockblockflöte, Tutzing 1992, str. 69.

34 ZAL, Conscriptions..., ibidem. 
obeh lastnikov preberemo le strugar, medtem ko je v Imeniku mestjanov Simon zapisan kot izdelovalec glasbil ("Instrumentenmacher") z meščanskimi pravicami, ki so mu bile podeljene 30. januarja $1801 .{ }^{35}$ Ob njem je vpisan še Ignacij Unglerth, strugar, imetnik meščanskih pravic od 21. marca 1806 . leta. ${ }^{36}$ Zanj nimamo nikakršnih drugih podatkov in ne ohranjenih glasbil, a je mogoče, da sta bila v sorodu.

Nekaj imen izdelovalcev pihal, nekoč delujočih v naših mestih, navaja tuja literatura, ki temelji na evidentiranih in ohranjenih instrumentih v evropskih in ameriških muzejih ter v zasebnih zbirkah. V najobširnejšem leksikonu o izdelovalcih pihal in njihovi dediščini, ki ga je po starejšem leksikonu Lyndesaya G. Langwilla ${ }^{37}$ napisal William Waterhouse, ${ }^{38}$ najdemo dva ljubljanska mojstra in Ptujčana. Kot Ljubljančana sta omenjena "W. Leutgeb ${ }^{39}$ in "Simon Unglerth" ${ }^{40}$ kot Ptujčan pa "M. Pöhn ${ }^{41}$

Za prvega je ob začetnici imena (krstno ime ni izpisano) in priimku podatek, da je bil Leutgeb izdelovalec lesenih pihal $\mathrm{z}$ meščanskimi pravicami v Ljubljani v zgodnjem 19. stoletju in da se je v neznani privatni zbirki ohranila flavta $z$ eno zaklopko ter $\mathrm{z}$ značko: "W. Leutgeb, Laibach ${ }^{4} .{ }^{42} \mathrm{Kljub}$ temu da je na voljo precej podatkov o pihalih zasebnih zbirk po Evropi in Združenih državah Amerike, te flavte ni na seznamih. Po Waterhousu sodeč je omenjeno glasbilo tip prečne flavte s konca 18. oziroma iz zgodnjega 19. stoletja, ko še najdemo tako imenovani baročni tip flavt z eno samo zaklopko. Naprednejši izdelovalci so že od konca 18. stoletja izdelovali flavte s štirimi zaklopkami, kar je omogočalo spretnejše igranje in boljše prilagajanje obsegu partitur $\mathrm{z}$ vse bogatejšo harmonijo. Omenjena flavta W. Leutgeba je kaj lahko nastala v zgodnjem 19. stoletju, kajti nekateri izdelovalci so se zavezali tradiciji in niso sledili naprednejšim tokovom. Po takšnih izdelkih so povpraševali manj zahtevni flavtisti, kot so večkrat bili tudi člani vojaških godb, kar je bilo seveda odvisno od poustvarjalne ravni godbenega korpusa, pa tudi drugi.

V ljubljanskem Imeniku mestjanov je zabeležen strugar s podobnim, le drugače zapisanim priimkom kot zgoraj. Pri zapisovanju imen in priimkov v prejšnjih stoletjih niso bili najbolj natančni, pa čeprav je šlo za uradne zaznamke. Tako najdemo v omenjenem imeniku pod zaporedno št. 378 Johanna (Ivana) Leitgeba, strugarja, ki je postal meščan 13 . januarja $1804 .{ }^{43}$ Oba sta lahko isti osebi ali vsaj v sorodstveni zvezi, ne glede na različno zapisana priimka. Tudi začetnica imena, ki je v tem primeru različna, še ne dokazuje dveh oseb. Med izdelovalci glasbil namreč najdemo veliko primerov, ko je signatura na instrumentih ostala enaka skozi enega ali več rodov izdelovalcev. Na številna vprašanja bi bilo mogoče odgovoriti le, če bi poznali glasbilo, po katerem je Waterhous predstavil ljubljanskega mojstra. Morda

35 ZAL, Imenik mestjanov deželnega glavarnega mesta ljubljanskega 1786-1867, Laibach 1867, sign. 767, zap. št. 799.

36 Ibidem, zap. št. 798.

37 Lyndesay G. Langwill, An Index of Musical Wind-Instrument Makers, izdaje 1960, 1962, 1972, 1974, 1977 in 1980.

38 William Waterhouse, The New Langwill Index, Dictionary of Musical Wind-Instrument Makers and Inventors, London 1993.

39 W. Waterhouse, ibidem, str. 234 in 462.

40 Ibidem, str. 409 in 462.

41 Ibidem, str. 305 in 476.

42 W. Waterhouse, ibidem, str. 234.

43 Imenik mestjanov ..., ibidem, zap. št. 378. 
so Simon in Ignaz Unglerth ter Leutgeb (ali Leitgeb) strugarski mojstri, ki so kot anonimneži zabeleženi v gradivu o obrteh z začetka 19. stoletja; Slokarjev popis omenja za leto 1809 tri strugarske mojstre ter dva pomočnika. ${ }^{44}$

\section{Simon Unglerth (1778-1854)}

Za Simona Unglertha (tudi Ungelerth, Ungeleerth, Ungelert) je v Waterhousu več oprijemljivejših podatkov. Poleg leta rojstva (1778) in natančnega datuma smrti (umrl je 14. novembra $1854 \mathrm{v}$ Ljubljani) je Unglerth označen kot izdelovalec lesenih pihal ${ }^{45} \mathrm{v}$ času od $1798 / 1800$ do $1854 .{ }^{46} \mathrm{O}$ virih, ki bi pojasnili začetno letnico njegovega delovanja, nimamo drugih podatkov kot vpis $\mathrm{v}$ knjigo mestjanov, datiran $\mathrm{z}$ letom 1801. Obstoja možnost, da je avtor leksikona podatke povzel po nam neznanih virih. Nekaj več biografskih podatkov, podprtih $z$ arhivskim gradivom, zajema že omenjena knjiga Mariane Betz" ${ }^{47} \mathrm{ki}$ je raziskovala izvor, izdelovanje ter repertoar tako imenovanega čakana, svojstvene flavte v obliki sprehajalne palice, ki je bila $\mathrm{v}$ prvi polovici prejšnjega stoletja na širšem avstrijskem zelo popularna. V knjigi "Der Csakan und seine Musik" najdemo nekaj vitalnih podatkov, povzetih po mestnem arhivu Ljubljane ter frančiškanske cerkve. Avtorica nas poduči, da se je Simon Unglerth leta 1803 poročil z Lucijo Schlechter ter da se jima je osem let kasneje rodil sin Ferdinand Johann (23.9.1811), ki bi naj zgodaj umrl. Simon je preminil 1854. leta, njegova žena pa dvanajst let kasneje (1866). Unglerth je veljal za premožnega moža, kar potrjuje lastništvo več hiš v mestu. ${ }^{48}$ Druge podrobnosti iz njegovega življenja zaenkrat niso znane. Če upoštevamo dejstva o gibanju strugarske obrti v Ljubljani v prvi polovici prejšnjega stoletja, lahko med strugarji tega časa poimensko prepoznamo tri Unglerthe, a le za Simona vemo, da je bil tudi izdelovalec glasbil, o čemer pričajo njegovi ohranjeni izdelki.

Med glasbili s signaturo Unglerthove delavnice sta $\mathrm{v}$ Waterhousu v kratkem opisana dva: čakan, ki je del zbirke v Musikhistorisk Museum v Kobenhavnu, in basetni rog iz Metropolitanskega muzeja v New Yorku. ${ }^{49}$ Ob omenjenih so se ohranili še nekateri redki instrumenti: klarinet, flavta in dva zgornja dela pihala, verjetno flažoleta. Vsi so del bogate zbirke glasbil v Pokrajinskem muzeju na Ptuju. Čeprav je bera ohranjenih Unglerthovih izdelkov majhna, njena raznolikost dokazuje, da je v delavnici ljubljanskega mojstra nastajal raznovrsten instrumentarij, značilen za širši evropski prostor $\mathrm{v}$ prvi polovici prejšnjega stoletja. Tedanja izvajalska praksa je narekovala rabo različnih pihal, ki so se razlikovala po velikosti, uglasitvah, me-

\footnotetext{
44 Prim. I. Slokar, Zgodovina rokodelstva..., ibidem, str. 25 in 58.

45 Izraz "lesena pihala" je $\mathrm{v}$ tujih jezikih zelo običajen (ang.: woodwind, nem.: Holzblasinstrumente, fr.: bois, it.: madera) ter označuje skupino pihal, kot so klarinet, flavta, oboa, saxofon in druga $z$ enojnim ali dvojnim trstnim jezičkom, ki imajo značilen cilindričen ali koničen rahlo razširjen odmevnik. Večinoma so izdelani iz lesa, sem pa sodijo tudi flavte in saxofoni, pa čeprav so danes kovinski. Ta izraz se je udomačil v 19. stoletju in se kljub številnim spremembam $\mathrm{v}$ materialih ni spremenil, med tem ko so $\mathrm{v}$ starejših obdobjih podobna glasbila imenovali "pihalni instrumenti" ali "pihala".

46 Glej W. Waterhouse, ibidem, str. 409 in 462.

47 Prim. M. Betz, ibidem, str. 68-69.

48 ZAL, Conscriptions.., ibidem.

49 Prim. W. Waterhouse, ibidem, str. 409.
} 
haniki in še čem. Največje je bilo povpraševanje po prečnih flavtah, klarinetih, basetnih rogovih kot vrsti nižje uglašenih klarinetov, oboah in fagotih, godbe na pihala so ob omenjenih uporabljale še različne flažolete in pikolo, za izvajanje lahkotnejše glasbe pa so bila med popularnimi pihala $v$ obliki sprehajalnih palic, med katerimi sta bila najbolj razširjena čakan, oblika blokflavte in "Stockflöte", v palico vdelana prečna flavta. Unglerthovi ohranjeni instrumenti, javne pohvale in nenazadnje njegovo premoženjsko stanje kažejo, da je mojster uspešno sledil potrebam svojega časa. V Ljubljani so bile potrebe po pihalih v prvi polovici prejšnjega stoletja, sodeč po intenziteti poustvarjalne glasbene kulture ter naraščajočem institucionalnem šolstvu, tolikšne, da so zagotavljale preživetje enemu ali večim izdelovalcem lesenih pihal. Kakor kažejo muzejski eksponati, so Unglerthovi izdelki dobro konkurirali ponudbi z Dunaja, Gradca in od drugod.

1. Čakan (madž. csákány, v rabi tudi czakan, csakan, nem. Stockblockflöte) ${ }^{50}$ (čakan z glavičem), Simon Unglerth, Ljubljana, zgodnje 19. st.; signatura na glavi: " (dvoglavi orel) SIMON / UNGLERTH / INSTRUM.MACHER / IN LAYBACH. / (šesterokraki znak)“; provenienca: iz muzeja glasbil v Københavnu (Musikhistorisk Museum og Carl Claudius' Samling), izbirka Carla Claudiusa; opis: čakan oziroma blokflavta $\mathrm{v}$ obliki sprehajalne palice $\mathrm{z}$ glavičem oz. lesenim čepom z dvema majhnima luknjicama za pihanje, rahlo konično oblikovan instrument sestavljajo: glava $z$ glavičem na navoj, srednji del in noga, zaključena $z$ okroglasto konico temnejše barve, dele ločujejo značilni roževinasti obročki, na srednjem delu je 7 luknjic za prebiranje s prsti, osmo pokriva medeninasta zaklopka kvadratne oblike s podaljškom za mezinec, palčna luknjica za prepihovanje je zelo majhna, nižje od pokrite luknjice sta ob straneh dve zvočnici; uglasitev: A; mehanika: 1 zaklopka; material: lakirani javor (glavič in konica palice sta temno lužena), medenina; mere: celotna dolžina: $87 \mathrm{~cm}$, glava: $17,3 \mathrm{~cm}$, srednji del: $35,9 \mathrm{~cm}$ (cev je v spodnjem delu v dolžini $3,6 \mathrm{~cm}$ polna), spodnji del: $39 \mathrm{~cm}$; Musikhistorisk Museum og Carl Claudius' Samling, inv. št. MMCCS no. Cl 427. ${ }^{51}$

2. Basetni rog, Simon Unglerth, Ljubljana, zgodnje 19. st.; signatura a) na sodčku: "(dvoglavi orel) / SIMON / UNGLERTH", b) na zgornjem delu telesa: "(dvoglavi orel) / SIMON / UNGLERTH / INSTR.MACHER / IN LAYBACH “, c) na sp. delu telesa in na zabojčku: "(dvoglavi orel) / SIMON / UNGLERTH / INSTRUM. MACHER / IN LAYBACH“; provenienca: The Crosby Brown Collection of Musical Instruments,

50 Čakan je po klasifikaciji uvrščen v družino blokflavt madžarskega porekla. Madžarsko etimološko poimenovanje ima več razlag, povezanih z ljudskimi glasbili v obliki različnih orodij. Čeprav ne vemo natančno, kdo je prvi izdelal pihalo v obliki sprehajalne palice, so si strokovnjaki edini, da je čakan, namenjen izvajanju umetne glasbe, nastal na začetku 19. stoletja. Za njegovega iznajditelja velja Anton Heberle (rojstni podatki niso znani), virtuoz na flavti, ki je leta 1807 objavil prvo skladbo za ta instrument. Čakan je bil najbolj popularen in moden v veselih družbah na Dunaju ter v njegovi okolici. V prvih treh desetletjih 19. stoletja so čakanu namenili lepo število didaktičnih učbenikov, med skladbami pa je največ plesnih oblik za duete, tria in večje komorne zasedbe, ki so jih napisali danes manj znani avstrijski skladatelji, veliko pa je bilo tudi priredb del eminentnejših mojstrov od Mozarta, Beethovna in Rossinija do Johanna Straussa starejšega. Večina ohranjenih glasbil je datirana v prvo polovico 19. stoletja, nato pa je popularnost čakanov ugašala. Proti koncu stoletja je povsem utonil v pozabo. O zgodovini tega instrumenta ter o repertoarju glej M. Betz, ibidem.

51 Kustodinji glasbenega muzeja $\mathrm{v}$ Københavnu Lisbet Torp se zahvaljujem za pomoč pri kataloškem opisu instrumenta, hvala tudi vodstvu muzeja za prijazno dovoljenje za objavo fotografij Unglerthovega čakana. 


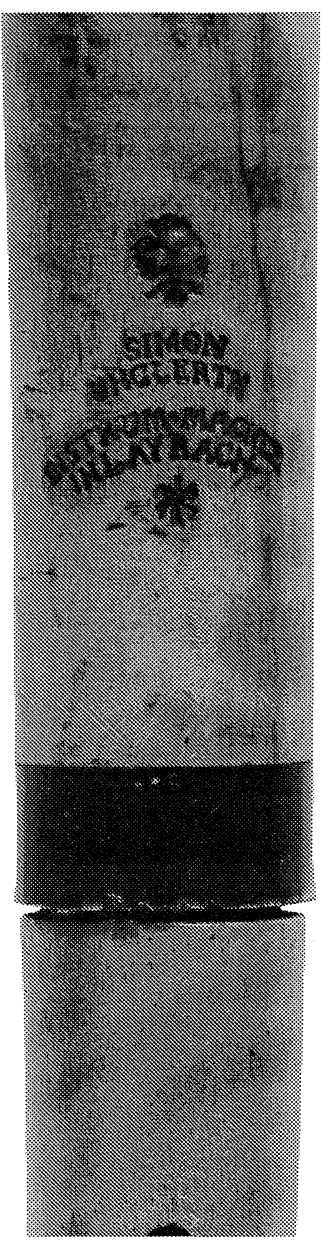

Slika 2. Čakan, Simon Unglerth, Ljubljana, zg. 19. st., detajl s signaturo, instrument hrani Musikhistorisk Museum og Claudius' Samling, København, foto: Ole Woldbye.

v Metropolitanskem muzeju od leta 1889; opis: instrument sestavlja osem delov in je nekoliko predelan (zgornji del telesa je skupaj s sodčkom sekundaren, povzet po drugem basetnem rogu istega muzeja), nekoč je bil v gornjem delu rahlo ukrivljen, sedaj je raven; uglasitev: F, mehanika: 6 enojnih luknjic, 8 zaklopk (4 odprte, 4 zaprte); material: zelenika, roževina, medenina; Metropolitan Museum New York, Musical Instruments Collection, inv. št. NY MM, 89.4.2143.52

3. Flavta, Simon Unglerth, Ljubljana, zg. 19. st.; signatura a) glava: "(lev s kronico) / S.UNGLERTH / C", b) zgornji del: "(lev s kronico) / S. UNGLERTH / LAIBACH / C“, c) noga: "(lev s kronico) / Cu; provenienca: leta 1997 je ptujski muzej flavto odkupil od Miloša Pahorja iz Trsta; opis: flavta je rahlo konične oblike,

52 Dokumentacijo o instrumentu hrani Metropolitan Museum New York, Department of Musical Instruments. Direktorju zbirke glasbil, dr. Laurencu Libinu, se zahvaljujem za sprejem in dostop do gradiva. 


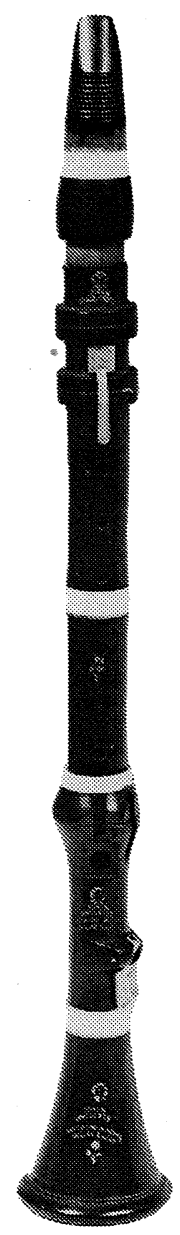

Slika 3. Klarinet, Simon Unglerth, Ljubljana, zg. 19. st., Pokrajinski muzej Ptuj, foto: Bine Kovačič.

sestavlja jo pet delov, ločenih z obročki iz slonovine, iz slonovine sta tudi čep na glavi in vijak - zaključek noge; uglasitev: C; mehanika: 4 zaprte zaklopke ovalne oblike; material: zelenika, slonovina, medenina; mere: celotna dolžina: $61 \mathrm{~cm}$; Pokrajinski muzej Ptuj (PMP), inv. št. GL 96 S. ${ }^{53}$

4. Es klarinet, Simon Unglerth, Ljubljana, zg. 19. st.; signatura a) sodček: "(dvoglavi orel) / SIMON / UNGLERTH", b) srednji del: "(planika ?)", c) spodnji del: "(dvoglavi orel) / SIMON / UNGLERTH / INSTRUM. MACHER / IN LAYBACH", d) na odmevniku: "(dvoglavi orel) / SIMON / UNGLERTH / INSTRUM. MACHER / (planika?)“; provenienca: po ustnem izročilu iz zapuščine godbe ptujske mestne garde; opis: majhen, visoko uglašen klarinet ima štiri dele, ločene $z$ izbočenimi obročki iz slonovine in roževine (zgornji, verjetno roževinast obroček pri sodčku manjka),

53 Iz dokumentacije kulturnozgodovinskega oddelka PMP. 
nekoč je bil namenjen igranju v pihalnih godbah, cilindrično telo ima šest odprtih luknjic za prebiranje s prsti ter pet kvadratnih zaklopk (dve sta izgubljeni); uglasitev: Es; mehanika: 6 odprtih luknjic, 5 zaklopk; material: ebenovina (?), slonovina, roževina, medenina; mere: celotna dolžina: $43,5 \mathrm{~cm}$; PMP, inv. št. GL 18 S. ${ }^{54}$

5. Dela flažoleta (?), ${ }^{55}$ Simon Unglerth, Ljubljana, zg. 19. st. ; signatura a) "(planika ?) / SIMON UNGLERTH / 3 ", b) "(planika ?) / SIMON / UNGLERTH / (znak ?)“; provenienca: neznana; opis: oba kosa sta zgornja dela instrumenta podobnega tipom flažoletov, prvi ima štiri luknjice za prebiranje s prsti, eno palčno in eno resonančno, drugi je brez vsake luknjice; uglasitev: (?), mehanika: (?), material: zelenika; mere: oba dela merita po $25 \mathrm{~cm}$; PMP, inv. št. GL 64 S in GL 25 S. ${ }^{56}$

Pri dataciji instrumentov je potrebno upoštevati mnoge dejavnike, kot so oblika, mehanika, material in ne nazadnje signatura izdelovalca. Ohranjeni Unglerthovi instrumenti so stilno in po mehaniki dokaj enoviti, zato jih datiramo v zgodnje 19. stoletje. Upoštevajoč različne signature, pa lahko njegove izdelke datiramo $\mathrm{v}$ različna obdobja mojstrovega delovanja. Flavta in oba dela, pripisana flažoletu, sodijo v zgodnejše obdobje, verjetno kmalu po letu 1801, ko je mojster dobil meščanske pravice in je začel s samostojnim delom. Signaturo tega prvega obdobja sestavljajo znak delavnice, na flavti je to lev s kronico, na drugih dveh pa rožica, ki še najbolj spominja na planiko, nato sta ime in priimek izdelovalca ter kraj (na obeh nepopolnih delih je le znak, začetnica imena in priimek). Vsaka delavnica je bila prepoznavna po imenu in priimku mojstra pa tudi po lastnem znaku. Signature so mojstri večkrat spreminjali, običajno čez nekaj let oziroma takrat, ko so zaradi višje kvalitete oziroma izboljšav na svojih izdelkih dobili posebne obrtne privilegije višjega ranga. Na instrumentih je to največkrat izraženo tako, da so znak delavnice zamenjali z dvoglavim orlom, državnim simbolom, nato so sledili ime, priimek, poklic (največkrat najdemo oznako "Instrumentenmacher"), kraj delovanja, na koncu pa je bil še kakšen shematiziran znak. Lep primer takšnih signatur so Unglerthov čakan, basetni rog in klarinet. Tako predvidevamo, da so slednji nastali v času, ko je mojster že imel obrtne privilegije. Oblika in kvaliteta Unglerthovih instrumentov izdajajo dobrega mojstra, ki se je najbrže zgledoval pri dunajskih izdelovalcih. Dunaj je od konca 18. pa skozi naslednje stoletje slovel po odličnih delavnicah. Mariane Betz celo namiguje, da bi naj bil Unglerth na Dunaju rojen, kar pa ni dokazano. Vsekakor je mogoče, da se je na Dunaju izučil, a o njegovi vajeniški in pomočniški dobi ni znanih podatkov. Simon Unglerth je pri delu uporabljal najboljše materiale, kakor so zelenika, ebenovina in slonovina, kar med drugim potrjuje, da je posel dobro cvetel ter da je delal za zahtevnejše naročnike.

Po Unglerthu kot da je izdelovanje lesenih pihal v Ljubljani zamrlo, kajti arhivi in ohranjeni instrumenti o strugarjih glasbilarjih ne spregovore več. Izdelovanje pihal pa je v posameznih primerih vsaj za krajši čas zaživelo tudi v nekaterih drugih

54 Dokumentacijo hrani kulturnozgodovinski oddelek PMP.

55 Oba primerka sta zgornja dela pihala, ki ga še ni bilo mogoče do kraja opredeliti. Po dosedanjih raziskavah sta oba najbližja oblikam flažoletov iz zgodnjega 19 . stoletja.

56 Dokumentacijo hrani kulturnozgodovinski oddelek PMP. 


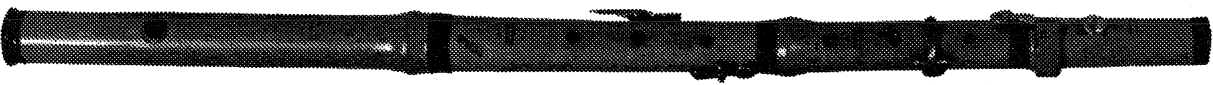

Slika 4. Flavta, Michael Pöhm, Ptuj, ok.1800, Pokrajinski muzej Maribor, foto: Bine Kovačič.

slovenskih krajih. Na Ptuju je na prehodu iz 18. v 19. stoletje deloval Mihael Pöhm, v Mariboru pa sredi prejšnjega stoletja neki Poje.

\section{Michael Pöhm (deloval ob koncu 18. stoletja)}

Na Michaela Pöhma nas je opozoril zaznamek o njegovi oboi, ki je bila pred drugo svetovno vojno spravljena v glasbeni zbirki Joanneuma v Gradcu, a je med vojno izginila neznano kam. ${ }^{57}$ Pred kratkim pa se je izkazalo, da sta do danes ohranjeni dve njegovi flavti, ena v Pokrajinskem muzeju v Mariboru, druga v Museo Civico v Milanu.

Priimek Pöhm se v gradivu ptujskega arhiva pogosto pojavlja. Največ podatkov razberemo iz Vpisne knjige meščanov mesta Ptuja. ${ }^{58}$ Prvi je zabeležen Michael Pöhm (starejši, op. D. Koter), in sicer kot četrtnik leta 1725.59 Zagotovo je imel meščanske pravice, sicer bi ne mogel opravljati nadzorniške službe. V letu 1747 je bil med meščane sprejet Gottfridt, kolarski mojster, ${ }^{60}$ štiri leta za njim je privilegije dobil Jakob, lončarski mojster, ${ }^{61} 1759$ pa je zaprisegel Johann Michael, strugar. ${ }^{62}$ Slednji je šest let kasneje vpisan kot četrtnik, enako pa spet čez naslednjih šest let. ${ }^{63}$ Leta 1772 se ponovno pojavi ime Michael Pöhm, in sicer med meščani, ki so zaprisegli 14. decembra. ${ }^{64}$ Ker je pri njegovem imenu pripis "četrtnik", je omenjeni najverjetneje identičen $z$ Johannom Michaelom. Potrditev ali odpustitev četrtnikov je magistrat opravljal vsako leto, zatorej gre v tem primeru za isto osebo. Potrjen je bil tudi naslednje leto, nato pa ne več. Decembra 1782 je med novimi meščani vpisan Michael Pöhm, strugar, ${ }^{65}$ ki je najverjetneje izdeloval tudi lesena pihala. V letu 1790 je vpisan kot vojak ptujskega meščanskega vojaškega lovskega korpusa ("Bürgerlicher Jäger Korps"), ki je 30. avgusta tega leta v Betnavi pri Mariboru izkazal vojaško čast Leopoldu II. Ta je skupaj z neapeljskim kraljevskim parom potoval na Dunaj. ${ }^{66}$ Michael je na seznamu kot vojak, prav mogoče pa je bil član vojaške godbe istega

\footnotetext{
57 Prim. G. Stradner, Musikinstrumente in Grazer Sammlungen, Wien 1986, str. 33.

58 Originalen naslov: "Bürgerliches Einschreib Buch/der Landeß Fürstl(ichen) Kammer Stadt Pettau/ darinen Begriffen waß vor Bürger nach/ der Feuers Brunst den 16.(ten) May 1684 / gewesen, und nachher wiederum geworden, den/ Standt*, Rokopisna zbirka ZAP, R - 30.

59 Prim. M. H. Masten, ibidem, str. 70.

60 Ibidem, str. 76.

61 Ibidem, str. 78.

62 Ibidem, str. 80.

63 Ibidem, str. 83 in 85.

64 Ibidem, str. 86.

65 Ibidem, str. 91.

66 Ibidem, str. 95-97.
} 
korpusa, za katero vemo, da je ob tej priložnosti tudi igrala. ${ }^{67}$ Ker je na seznamu celotne čete kot glasbenik le trobentar Bauer, predvidevamo, da so bili drugi godbeniki vpisani kot vojaki. Tri leta kasneje, ko se je meščanski korpus preimenoval v Meščanski konjeniški korpus ("Bürgerliche Cavallerie Corps"), je Michael še na seznamu, vendar s pripisom, da je izstopil. ${ }^{68}$ Drugih podatkov o Michaelu Pöhmu, strugarju in izdelovalcu lesenih pihal zaenkrat še ni. Njegov naslednik je najverjetneje postal Johann Pöhm, ki je dobil meščanske pravice kot strugarski mojster leta $1812,{ }^{69}$ ne vemo pa, če se je tudi on skušal v glasbilarstvu. Zadnji vpisani ptujski strugar je neki Joseph Duhatsch, sprejet med meščane deset let kasneje (1822). ${ }^{70}$

Michael Pöhm, ki je kot izdelovalec lesenih pihal deloval v zadnji tretjini 18. in morda še na začetku naslednjega stoletja, je izhajal iz družine, kjer so bile obrti, povezane $z$ obdelavo lesa, tradicionalne. Moški člani družine Pöhm so bili zagotovo spoštovani meščani, v kar nas prepričajo njihove četrtniške in vojaške dolžnosti. Da je med Pöhmi tudi glasbilar, zagotovo ni naključje, kajti zgodovina ptujskega glasbenega življenja je toliko bogata, da je vsaj v določenem obdobju mesto potrebovalo izdelovalce glasbil. Iz ptujske glasbene preteklosti je največ znanega o mestnih muzikih, ki jih v različnih sestavih spremljamo od poznega srednjega veka naprej. Godba mestne garde, v kateri so zagotovo bila potrebna tudi pihala, je najbolj cvetela od druge polovice 18. stoletja, zato ne preseneča, da je prav v tem času na Ptuju deloval strugar, izdelovalec pihal, ki je bil hkrati tudi član mestne garde. Osebnost Michaela Pöhma zaenkrat izkazujejo le registrirani instrumenti v Gradcu, Mariboru in v Milanu.

1. Oboa, Michael Pöhm, Ptuj, 1796; signatura a) na srednjem delu: "M. PÖHM / PETTAU“, b) na odmevniku: "2 / 1796“; provenienca: nekoč v muzeju Joanneum v Gradcu, Abteilung für Kunstrgewerbe, uničena v drugi svetovni vojni; uglasitev: (?), mehanika: 2 srebrni zaklopki; material: ebenovina, slonovina, srebro; mere: celotna dolžina: $56 \mathrm{~cm}$; Joanneum Gradec, inv. št. KGW 1398. ${ }^{71}$

2. Flavta, Michael Pöhm, Ptuj, okrog 1800; signatura: "(stiliziran križec) / M. PÖHM / PETTAU، (enako so označeni vsi štirje deli); provenienca: Muzejsko društvo Maribor je flavto kupilo leta 1905 za 2 kroni, danes je v lasti Pokrajinskega muzeja Maribor; opis: prečna flavta tipa godbenih glasbil s konca 18. in začetka 19. stoletja, sestavljena je iz štirih delov, ločenih z roževino; uglasitev: C; mehanika: 4 medeninaste zaklopke, material: zelenika (sekundarno lakiran les), medenina; mere: dolžina: 60,5 cm; PM Maribor, inv. št. No. 4065.

3. Flavta, Michael Pöhm, Ptuj, okrog 1800; signatura: "M. PÖHN / PETTAU«, provenienca: neznana; opis: prečna flavta, sestavljena iz petih delov, ki jih ločujejo obročki iz roževine; uglasitev: C; mehanika: 4 zaklopke iz medenine; material: svetel les (?), medenina; mere: dolžina: $61 \mathrm{~cm}$; Museo degli Strumenti Musicali Milano, inv. št.: (vir številke ne navaja). ${ }^{72}$

67 Prim. Ferdinand Raisp, Pettau - Steiermarks älteste Stadt und ihre Umgebung, Graz 1858.

68 Prim. M. H. Masten, ibidem, str. 101-103.

69 Ibidem, str. 113.

70 Ibidem, str. 120.

71 Prim. Gerhard Stradner, Musikinstrumente in Grazer Sammlungen, Wien 1986, str. 33. 


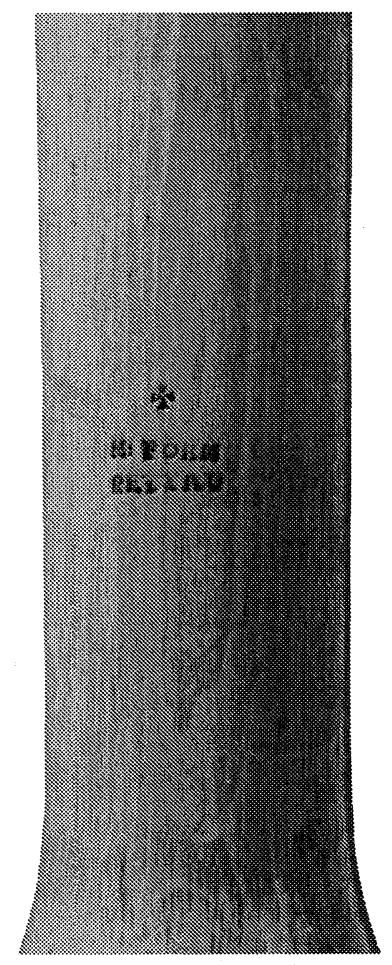

Slika 5. Flavta, Michael Pöhm, Ptuj, ok.1800, detajl s signaturo, Pokrajinski muzej Maribor, foto: Bine Kovačič.

Obe Pöhmovi flavti sta izdelani v podobnih manirah in kažeta na veščega glasbilarja. Njun estetki videz sicer ne dosega flavt najvišjega ranga iz začetka prejšnjega stoletja, vsekakor pa je Pöhm izdeloval času in potrebam primerna glasbila. Zdi se, da je mojster stremel $\mathrm{k}$ najvišjim idealom, v kar nas prepriča fotografija izgubljene oboe. Iz nje je razvidno, da je bila izdelana iz dragih materialov, kot so ebenovina, slonovina in srebro, instrument pa je odlikovala tudi skladna oblika, kakršna je značilna za boljše mojstre. ${ }^{73}$ Kakor smemo sklepati po fotografiji, se Pöhmova oboa od obeh flavt razlikuje po estetski plati, pa tudi po materialih. Imenitnejši instrumenti so bili običajno namenjeni bogatejšim naročnikom. Tako opažamo, da godbena glasbila niso dosegala najvišjih idealov. Med godbeniki najbrže ni bilo imenitnežev, narava igranja pa je zahtevala terenu prilagojena glasbila.

72 Prim. Museo degli Strumenti Musicali, Castello Sforzesco (razstavni katalog), Milano 1963, str. 153; W. Waterhouse, ibidem, str. 305. Instrumenti v milanskem muzeju že nekaj let niso na ogled širši javnosti, zato Pöhmove flavte doslej ni bilo mogoče natančneje raziskati. Posebno nas zanima signatura, kajti v omenjenem katalogu in leksikonu je priimek zapisan kot "Pöhn«.

73 Prim. Hans Sowinski, Steierische Volksmusikinstrumente, v: Musik im Ostalpenraum (Das Joanneum 3), Graz 1940, sl. 5 e. 
Slika 6. Flavta, Poje, Maribor, sreda 19. stoletja, Pokrajinski muzej Ptuj, foto: Boris Farič.

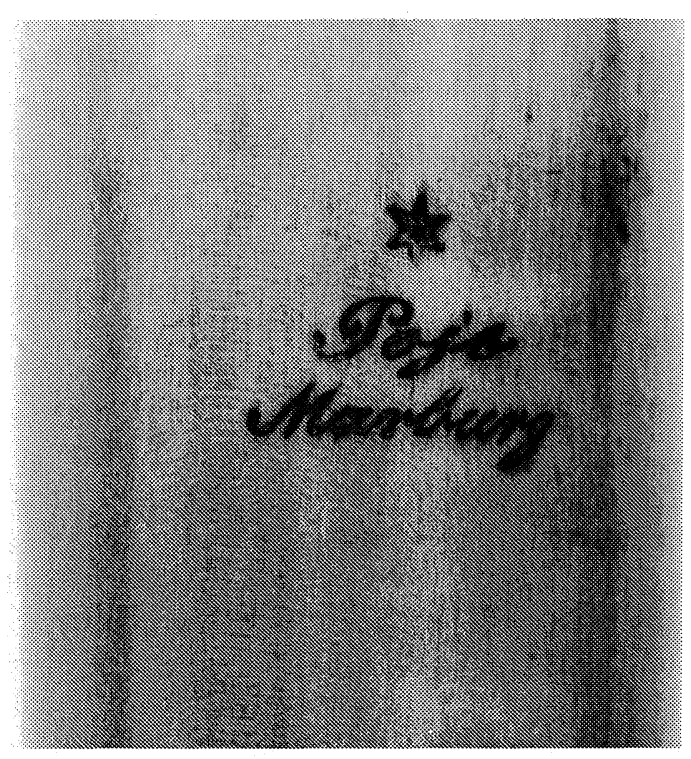

Slika 7. Flavta, Poje, Maribor, sreda 19. stoletja, detajl s signaturo, Pokrajinski muzej Ptuj, foto Boris Farič.

\section{Poje iz Maribora (deloval sredi 19. stoletja)}

Zadnji doslej odkriti izdelovalec lesenih pihal, kar jih je delovalo pri nas, je neki Poje iz Maribora iz srede prejšnjega stoletja. O njegovem življenju še ne vemo ničesar, o delu pa priča doslej edina registrirana flavta, shranjena $\mathrm{v}$ ptujskem muzeju.

Flavta, Poje, Maribor, sreda 19. st.; signatura: "(̌̌esterokraka zvezdica) / Poje / Marburg“ (enako na zgornjem in srednjem delu ter na nogi); provenienca: darilo Ptujčanke Irme Pirš 11.7. 1994; opis: prečna flavta $z$ rahlo koničnim telesom, sestavljena iz štirih delov, ločenih z roževinastimi obročki, glavo zapira temen čep, uglasitev: C, mehanika: 10 medeninastih zaklopk, 4 zaklopke tipa pokrovk so na srednjem delu, na nogi 6; material: zelenika, roževina, medenina; mere: dolžina: 70 $\mathrm{cm}$; PMP, inv. št. GL 76 S. ${ }^{74}$

Pojetova flavta odseva dobrega mojstra strugarja in vsestranskega poznavalca značilnosti mehanike. Instrument je $\mathrm{v}$ proporcih, materialu in mehaniki skladen $\mathrm{z}$ izdelki vplivnejših dunajskih mojstrov srede prejšnjega stoletja. Upamo, da bodo 
nadaljnje raziskave razkrile Pojetovo življenjsko pot skupaj z učno dobo in kraji delovanja. Zaenkrat ga enačimo $z$ izdelovalcem pihal $\mathrm{z}$ istim priimkom, ki je registriran v graškem muzeju Steierisches Volkskundemuseum, in sicer kot mojster klarineta $s$ signaturo "Poje / Gratz / C “. ${ }^{75}$ Stradner, avtor kataloga o graških glasbilih, je klarinet datiral v drugo polovico prejšnjega stoletja, ga v kratkem opisal, ni pa navedel nikakršnih biografskih ali drugih podatkov o izdelovalcu. Instrumenta sta izdelana na podoben način in sodita $\mathrm{v}$ isti čas. Morda sta bila mojstra $\mathrm{v}$ sorodu, ni pa izključena istovetnost oseb. V Mariboru in Gradcu so večkrat delovali izdelovalci glasbil z istim priimkom, za katere se je izkazalo, da so nekaj časa delovali v enem nato pa $\mathrm{v}$ drugem kraju.

\section{Zaključek}

Dosedanje raziskave kažejo, da so bili med domačimi strugarji redki izdelovalci pihal. Čeprav bodo nadaljnja proučevanja najbrže razkrila še kakšno ime ali pozabljen instrument s signaturo pri nas delujočega mojstra, lahko zaključimo, da poustvarjalna praksa kljub dokazani živahnosti ni narekovala intenzivnejše proizvodnje glasbil v naših krajih. Kakor je bilo doslej ugotovljeno tudi za nekatere druge glasbilarske obrti, so pri nas delujoči glasbeniki in amaterji največkrat kupovali glasbila, ki so bila izdelana v večjih in pomembnejših središčih, za kakršna sta slovela tudi Dunaj in Gradec. Ohranjena dediščine pa kljub temu kaže na nekaj dobrih domačih mojstrov, veščih strugarske obrti. Med omenjenimi najbolj izstopajo izdelki Simona Unglertha, ki so povsem primerljivi s pihali dunajskih izdelovalcev. Večina glasbil, ki jih je bilo mogoče doslej raziskati in primerjati $z$ dediščino drugod, kaže, da so se na Slovenskem delujoči mojstri najbolj prilagajali potrebam pihalnih godb. Takšna usmeritev delavnic je povsem razumljiva, kajti pihalne godbe so bile v naših krajih zelo popularne že stoletja nazaj.

\section{The Makers of Woodwinds in Slovenia and Their Heritage}

\section{Summary}

In Slovenia we have not long been dedicating ourselves to the development of instrument making, and even in "foreign" literature this subject is rarely mentioned. Up till now organ and violin making have been the most comprehensively examined, but research on the history and development of other crafts connected with the making of instruments has been conducted for only a short time. Therefore, this contribution is apparently the first historical survey of the making of woodwind instruments in Slovenia as well as of preserved instruments with the signatures of native masters; it is based on archival sources and preserved historical instruments. Although it has been ascertained that turners were working in Ljubljana by the second half of the 15th century, proof of the first turner, a maker of the wind instruments, comes as late as the end of the 18th century. We know of two of them from Ljubljana by name. The sources mention a W. Leutgeb, who worked at the end of the 18th

75 G. Stradner, ibidem, str. 107-108. 


\section{MUZIKOLOŠKI ZBORNIK • MUSICOLOGICAL ANNUAL XXXV}

century, and whose one-keyed flute has been preserved in a private collection the unknown owner. The other maker, Simon Unglerth (1778-1854), whose preserved instruments indicate that he was a skilled maker who modelled himself after the masters of the Vienna school, was known to be a successful maker of windwinds in Ljubljana. A flute, a clarinet, parts of a flageolet, a basset horn, and a walking-stick flute, all with the stamp of his workshop, are preserved in museums in Ptuj (Slovenia), Copenhagen, and New York. Michael Pöhm, who came from a well-known family of craftsmen with a long tradition, worked in Ptuj at the turn of the 19th century, but only two of his transverse flutes are preserved, which were made in accord with the requirements of a brass band characteristic of the beginning of the last century. In Maribor wind instruments were made by a certain Poje, whose flute, dated from the middle of the last century, is kept in the Ptuj museum. For the time being, we link him to a man named Poje from Graz. The modest heritage of woodwinds made by native masters and the archival material indicate that the making of wind instruments was not widespread in Slovenia. The need for wind instruments was most likely not such that a larger number of the craftsmen would have been able to make a living from it. The heritage in museums suggests that the musicians were buying their instruments elsewhere, mostly in Graz and Vienna, which were renown for their excellent makers of wind instruments as also other instruments from the end of the 18th century to the turn of the 20th century. 